Article

\title{
An Integrated Approach of Analytic Hierarchy Process and Triangular Fuzzy Sets for Analyzing the Park-and-Ride Facility Location Problem
}

\author{
Jairo Ortega ${ }^{1, * \mathbb{C}}$, János Tóth ${ }^{1}$, Sarbast Moslem ${ }^{1}{ }^{1}$, Tamás Péter ${ }^{2}$ and Szabolcs Duleba ${ }^{1}$ \\ 1 Department of Transport Technology and Economics, Faculty of Transportation Engineering and Vehicle \\ Engineering, Budapest University of Technology and Economics, Múegyetem rkp. 3, \\ 1111 Budapest, Hungary; toth.janos@mail.bme.hu (J.T.); moslem.sarbast@mail.bme.hu (S.M.); \\ duleba.szabolcs@mail.bme.hu (S.D.) \\ 2 Department of Control for Transportation and Vehicle Systems, Faculty of Transportation Engineering and \\ Vehicle Engineering, Budapest University of Technology and Economics, Múegyetem rkp. 3, \\ 1111 Budapest, Hungary; peter.tamas@mail.bme.hu \\ * Correspondence: ortega.jairo@mail.bme.hu
}

Received: 28 June 2020; Accepted: 23 July 2020; Published: 26 July 2020

\begin{abstract}
A park and ride (P\&R) system is a set of facilities where private vehicle users can transfer to public transport to complete their journey. The main advantage of the system is reducing the congestions problem in the central business district (CBD). Thus, the notion of symmetry is particularly important in multi-criteria decision aid (MCDA) because they are basic characteristics of the binary relationships used in modelling the preferences of decision-makers. The focal point of this study is evaluating the $\mathrm{P} \& \mathrm{R}$ facility system location problem from the experts' point of view. For this aim, an integrated multicriteria decision-making (MCDM) methodology is proposed to evaluate the location of the facilities of the P\&R system. The questionnaire survey was designed and estimated by 10 transport experts in the related field. The famous analytic hierarchy process (AHP) was adopted in a fuzzy environment, where the fuzzy sets have an efficient ability to manage the vague concepts in a specific way; moreover, it can mitigate the evaluator reasoning during decision-making. The hierarchical structure of the problem was established to evaluate a real-life problem in Cuenca city, Ecuador. The outcomes highlighted the "accessibility of public transport" as the most significant issue in the P\&R facility location problem. The obtained results provide more flexible facilities than the pure AHP method.
\end{abstract}

Keywords: park and ride (P\&R); park and ride location; multicriteria decision-making; analytic hierarchy process; triangular fuzzy sets; transport planning

\section{Introduction}

The sustainable urban mobility plan (SUMP) is widely used as a tool by transport authorities and planners for the sustainable development of the urban area. The SUMP is used as a manual to promote the transfer to more sustainable transport modes and provide safe, clean, and environmentally friendly solutions [1]. A policy proposed in the SUMPs method is the use of the Park and Ride (P\&R) system to solve the negative consequences of private vehicles in cities. Using this system, private vehicle users can travel to a central business district (CBD), and have a portion of the trip made in a private vehicle, before parking the vehicle to transfer to public transportation to complete their journeys [2-4]. Hence, the P\&R system is seen as a transport mode that encourages an intermodal shift towards a more sustainable transport mode in the urban area $[5,6]$. Therefore, its location requires a detailed study to be carried out in order to be beneficial to the success of the system [7]. 
The main factor to be studied in the P\&R system is its location, and the concept is that the facility should be close to public transportation stations (e.g., Light Rail Line (LRT), subway, bus), which could lead to the P\&R system having a facility at each station. Therefore, a set of criteria must be taken into account that further extends the concept mentioned above. In some cases, researchers and transport planners have designated the location based on the conception that the P\&R system allows the reduction of trips to the CBD [8], in other cases the P\&R system is considered as a transport mode, and a criterion that has been included in some studies is the distance between the origin and the facility, as well as between the facility and the destination. Among the most known criteria is the costs to use and implement the P\&R system [9]. In recent research, environmental criteria have been included, which has established the P\&R system as a tool that enables the reduction of vehicle emissions [10]. As mentioned, it is also the point of connection to public transport; thus, an accessibility criterion needs to be evaluated. All of the previous criteria lead to a sophisticated analysis of the location of the P\&R system facilities. In the case of emerging countries, a few studies regarding the P\&R system in Ecuador and South American countries have been carried out. This study is the result of a project in which the authors are working regarding the study of the $P \& R$ system, where other publications have already been made [11,12]. Therefore, transport experts have begun to use multicriteria decision-making (MCDM) applications to solve problems and improve citizens' quality through transport projects. According to the literature reviewed by the authors, no articles were found that have developed an analysis of park-and-ride facilities' location by the fuzzy analytic hierarchy process (FAHP) model in an emergent country and included an elaborate set of criteria.

The study is composed as follows: Section 2 provides the scientific information used to research the facilities' location in the P\&R system and MCDM methods. Section 3 details the methodology developed in our study. Section 4 describes our case study, Cuenca-Ecuador. In Section 5, we apply the methodology that was designed for our case study. Section 6 analyzes and discusses the results provided by applying our methodology. Finally, the contributions are presented in the conclusions section.

\section{Literature Review}

This section presents the main results of the research according to the P\&R location and the descriptions of the multicriteria method regarding the particular AHP method that is used in the methodology section. A number of studies have included the two approaches mentioned above.

Traffic saturation and pollution in cities caused by private vehicles have become commonplace in modern times. In order to mitigate these problems, some studies have proposed transport alternatives (e.g., pedestrian, bicycle, public transport, P\&R) [13-19]. The alternative that has been poorly studied is the $P \& R$ system, in which one of the factors that requires comprehensive expertise is its location, which, through methods and methodologies, has allowed which parameters are considered to be determined. Regarding the analysis of the P\&R location, several variables can be analyzed from different methods and methodologies. Transport planners tend to locate facilities close to public transport stations; however, according to this approach, a scenario arises where the number of facilities in the P\&R system should be the same as the number of public transport stations. Therefore, we describe a set of variables that have been studied by researchers about the P\&R system's location. Song et al. [20] suggested a model for the location of P\&R system facilities, in which the capacity of each facility is estimated; this model is known as an integrated planning framework. In addition, in recent years, interesting research has been carried out to combine other transport modes with the P\&R system, among which the most interesting ones are those that combine autonomous vehicles [21]. Thus, Chen and Kim [22] studied the possibility of establishing a model for the P\&R system that combines the railway system, which is based on the promotion of the use of public transport through the establishment of an environmental restriction that combines traffic assignment and modal split. Using a geographic information system (GIS), each facility's catchment area was determined, which is the potential demand [23]. Du [24] and Ni [25] studied the potential to optimize existing P\&R locations through an equilibrium multimodal choice that included three types of transport mode. Additionally, Cavadas and 
Antunes [26,27] extended the model of Aros-Veras et al. [28] and Holguin Veras et al. [29,30] to develop a discrete choice model to study transport alternatives, such as $P \& R$, private vehicles, and buses. Farhan and Murray [31,32] developed an optimization model to calculate the potential number of users of each P\&R facility, taking into account the following aspects: Covering as many users as possible, incorporating new $P \& R$ facilities, and establishing $P \& R$ facilities near public transport stations.

In order to analyze most of the variables mentioned about the location of facilities in the P\&R system, multicriteria decision-making models (MCDMs) are studied. These models have provided the creation of solutions to various problems in the area of transport, and even the models developed have solved a large number of problems concerning transport planning in the city's urban area. This model has started to be studied in detail by researchers around the world by linking the mobility components with the MCDM models [33-36]. A relevant multicriteria model is the so-called AHP method, based on the estimation and knowledge of decision-makers who, based on specific criteria, can make appropriate decisions regarding the resolution of a complex problem. In fact, it helps decision-makers find the solution that best addresses their requirements and judgment of the problem. The AHP method is subjective and is considered an assessment of expert knowledge; thus, it is unnecessary to involve a large sample in the analysis [37]. However, the AHP method has certain limitations, such as the decision criteria that the defendant has since the answer can be considered at a certain level as an argument related to a personal statement. The AHP method is a little imprecise because the criterion of perception, evaluation, correction, and choice is based on the decision-makers' preference, which has a significant influence on the results. In addition, dependencies between AHP variables often lead to some inconsistency in the weighting of criteria and create results contrary to reality [38]. Duleba and Moslem [39] examined the Pareto optimization of AHP weight vectors. Thus, the pairwise comparison matrices were used in a real case study; the authors achieved a modification of the weight of AHP vectors. The authors demonstrated through the results that their study of the AHP method could be optimized by adding it to the use of the analytic network process (ANP) modeling and simulation-based sensitivity evaluation $[40,41]$. The benefit of the model applied in addition to AHP varies according to the scenario used for this method and the type of study that it is most appropriate for. Thus, several mathematical and optimization methods have been employed in order to be able to analyze and improve the AHP results in terms of the precision of the outcome. Statistical considerations of the sensitivity analysis and innovation have been integrated into the AHP method using Monte Carlo Simulation [42,43]. Meena et al. [44] employed the well-known frequency ratio (FR) together with the AHP method, with the result being a hybrid spatial multicriteria assessment (SMCE) model, and obtained more accurate results in the multicriteria models. Both the SMCE and the FR require a set of data in the form of an inventory to prepare the model, and this is the major factor for achieving more precise results from the corresponding integrated model. However, such a set of inventory data is often not available for many of the decision-making problems. In another integration model, Ha et al. [45] used the AHP method to integrate it with fuzzy- Technique for Order of Preference by Similarity to Ideal Solution (TOPSIS ) to prioritize the performance of their methodology. Fuzzy theory is included in most of the instruments available in the MCDM since it is possible to interpret imprecise measurements within the mathematical operators for decision-making in the fuzzy domain. The fuzzy theory has been combined with AHP to develop several studies from its results [46-49]. The ANP is the advanced version that is most suited to complex decision problems.

The ANP is also combined with fuzzy theory in order to minimize possible errors and uncertainty inherent in the decision-making system [50-52], which is a more realistic approach given that several experts, who have very varied preferences and interests, are involved [53]. Few investigations have combined the MCDM methods and P\&R system to explore the criteria concerning their location; for instance, Szymon Fierek et al. [54] developed research that uses multiple criteria to evaluate the location of P\&R lots. The authors considered a case study of a city where $15 \mathrm{P} \& \mathrm{R}$ facilities were planned and then used the VISUM simulation tool to model the locations. The result is that the final ranking was obtained. In the same research line, an interesting investigation was developed that includes 
aspects, such as economic, social, urban, and environmental, to determine the location of the facilities. The authors used evaluation based on the distance from average solution (EDAS) in order to determine the decision regarding the location of a park-and-ride (P\&R) facility [55].

Based on the literature review concerning the P\&R location and MCDM, a research gap can be clearly indicated on the topic proposed in this article. In particular, there is a lack of evidence concerning the use of advanced models of MCDM in the planning of facilities for the P\&R system. This document aimed to introduce a combined model to support consensus decisions on P\&R system facilities' location. The current study is part of a research project called, "An Integrated study of Park-and-Ride Facilities for Sustainable Urban Mobility," where a number of scientific publications have been published.

\section{Methodology}

This section describes in detail how our methodology is being developed and then applied to our case study. The AHP is a well-proven decision-making methodology, which was developed by Saaty [56] to simplify complex decision problems. AHP is based on an additive weighting process, in which various relevant criteria are represented through their relative importance. The AHP approach was widely used by academics and professionals in many fields and problems, mainly in engineering fields like transport engineering field [39,57-60] in the construction engineering field [61], in architecture [62,63], and many different engineering fields. However, AHP has some restrictions, and to overcome these limitations, many researchers integrate fuzzy theories with AHP for providing more reliable and robust results [47,64,65]. Vinogradova et al. [66] adopted the AHP approach in a fuzzy environment to obtain the weight of criteria related to distant courses taught for students.

FAHP was conducted in this study to prioritize and classify the criteria for the location of facilities in the P\&R system in the city of Cuenca city, Ecuador. Consequently, the scale of fuzzy numbers and their linguistic scale were utilized for estimating the pairwise comparisons (PCs).

The hierarchy structure for the P\&R system for Cuenca city was constructed based on experts' opinions and the literature. The structure contains 6 main criteria in the first level and 19 sub-criteria in the second level.

The geometric mean approach was used to aggregate the evaluators' responses, and the final scores were calculated and prioritized. In order to ensure the quality and authenticity of the data collected, consistency tests were carried out. The mathematic notion for the FAHP evaluation was adopted from [67]. The author conducted a fuzzy logic technique by developing a questionnaire survey with triangular fuzzy number scales. The following formulas are merely applications in our research for the newly created integrative decision model. We introduce the formulas in detail in order to give insight into the computational process.

A fuzzy number $\widetilde{A}$ on $\mathbb{R}$ is a triangular fuzzy number if its membership function $\mu_{\widetilde{A}}(x): \mathbb{R} \rightarrow[0,1]$ is equal to the consequential Formula (1):

$$
\mu_{\widetilde{A}}(x)= \begin{cases}\frac{x-d}{m-d}, & d \leq x \leq m \\ \frac{h-x}{h-m}, & m \leq x \leq h \\ 0, & \text { otherwise }\end{cases}
$$

From Equation (1), $d$ and $h$ are the inferior and superior bounds of the fuzzy number $\widetilde{A}$, and $m$ is the modal value for $\widetilde{A}$ (see Figure 1). The triangular fuzzy number can be exhibited by $\widetilde{A}=(d, m, h)$. 


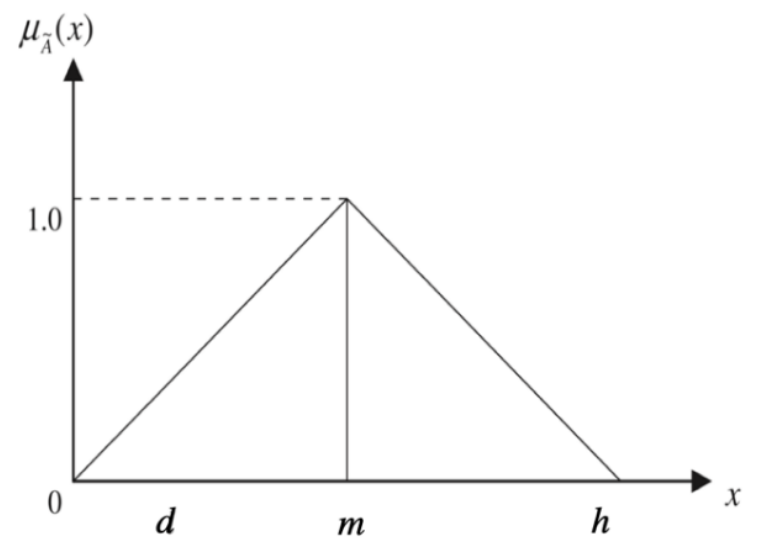

Figure 1. The membership functions of the triangular fuzzy number.

The operational laws of the triangular fuzzy number $\widetilde{A_{1}}=\left(d_{1}, m_{1}, h_{1}\right)$ and $\widetilde{A_{2}}=\left(d_{2}, m_{2}, h_{2}\right)$ are blazon as consecutive formulas as the addition (2), multiplication (4), division (5), and reciprocal (6) of the fuzzy numbers. In our computational procedure, all formulas were applied.

The following equation shows the addition of the fuzzy number $\oplus$ :

$$
\widetilde{A_{1}} \oplus \widetilde{A_{2}}=\left(d_{1}, m_{1}, h_{1}\right) \bigoplus\left(d_{2}, m_{2}, h\right)=\left(d_{1}+d_{2}, m_{1}+m_{2}, h_{1}+h_{2}\right) .
$$

The following equation shows the multiplication of the fuzzy number $\otimes$ :

$$
\widetilde{A_{1}} \otimes \widetilde{A_{2}}=\left(d_{1} d_{2}, m_{1} m_{2}, h_{1} h_{2}\right) \text { for } d_{1}, d_{2}>0 ; m_{1}, m_{2}>0 ; h_{1} h_{2}>0 .
$$

The following equation shows the division of the fuzzy number $\varnothing$ :

$$
\widetilde{A_{1}} \varnothing \widetilde{A_{2}}=\left(\frac{d_{1}}{h_{2}}, \frac{m_{1}}{m_{2}}, \frac{h_{1}}{d_{2}}\right) \text { for } d_{1}, d_{2}>0 ; m_{1}, m_{2}>0 ; h_{1} h_{2}>0 .
$$

The following equation shows the reciprocal of the fuzzy number:

$$
\widetilde{A}^{-1}=\left(d_{1}, m_{1}, h_{1}\right)^{-1}=\left(\frac{1}{h_{1}}, \frac{1}{m_{1}}, \frac{1}{d_{1}}\right) \text { for } d_{1}, d_{2}>0 ; m_{1}, m_{2}>0 ; h_{1} h_{2}>0 .
$$

In the incumbent research, the computational technique was based on the sequent fuzzy numbers that are defined in Table $1[67,68]$.

Table 1. The scale of fuzzy numbers and their linguistic scale.

\begin{tabular}{cc}
\hline Linguistic Scale of Importance & Scale of Fuzzy Number \\
\hline Perfect & $(8,9,10)$ \\
Absolute & $(7,8,9)$ \\
Very good & $(6,7,8)$ \\
Fairly good & $(5,6,7)$ \\
Good & $(4,5,6)$ \\
Preferable & $(3,4,5)$ \\
Not bad & $(2,3,4)$ \\
Weak advantage & $(1,2,3)$ \\
Equal & $(1,1,1)$ \\
\hline
\end{tabular}

The employed PC matrices were constructed based on the hierarchical structure of criteria, as shown in figure on page 9. Linguistic terms were assigned to the PCs by asking which criteria are 
more treasured than the other with respect to the main goal. As $\widetilde{A}$ is the biggest matrix $(5 \times 5)$ in the second level as an example in (6), we demonstrate the fuzzification of the scale values for this case:

$$
\widetilde{A}=\left[\begin{array}{ccccc}
\widetilde{a}_{11} & \widetilde{a}_{12} & \widetilde{a}_{13} & \widetilde{a}_{14} & \widetilde{a}_{15} \\
\widetilde{a}_{21} & \widetilde{a}_{22} & \widetilde{a}_{23} & \widetilde{a}_{24} & \widetilde{a}_{25} \\
\widetilde{a}_{31} & \widetilde{a}_{32} & \widetilde{a}_{33} & \widetilde{a}_{34} & \widetilde{a}_{35} \\
\widetilde{a}_{41} & \widetilde{a}_{42} & \widetilde{a}_{43} & \widetilde{a}_{44} & \widetilde{a}_{45} \\
\widetilde{a}_{51} & \widetilde{a}_{52} & \widetilde{a}_{53} & \widetilde{a}_{54} & \widetilde{a}_{55}
\end{array}\right]=\left[\begin{array}{ccccc}
\widetilde{a}_{11} & \widetilde{a}_{12} & \widetilde{a}_{13} & \widetilde{a}_{14} & \widetilde{a}_{15} \\
1 / \widetilde{a}_{12} & \widetilde{a}_{22} & \widetilde{a}_{23} & \widetilde{a}_{24} & \widetilde{a}_{25} \\
1 / \widetilde{a}_{13} & 1 / \widetilde{a}_{23} & \widetilde{a}_{33} & \widetilde{a}_{34} & \widetilde{a}_{35} \\
1 / \widetilde{a}_{14} & 1 / \widetilde{a}_{24} & 1 / \widetilde{a}_{34} & \widetilde{a}_{44} & \widetilde{a}_{45} \\
1 / \widetilde{a}_{15} & 1 / \widetilde{a}_{25} & 1 / \widetilde{a}_{35} & 1 / \widetilde{a}_{45} & \widetilde{a}_{55}
\end{array}\right]
$$

where:

$$
\widetilde{a}_{i j}= \begin{cases}\widetilde{9}^{-1}, \widetilde{8}^{-1}, \widetilde{7}^{-1}, \widetilde{6}^{-1}, \widetilde{5}^{-1}, \widetilde{4}^{-1}, \widetilde{3}^{-1}, \widetilde{2}^{-1}, \widetilde{1}^{-1}, \widetilde{1}, \widetilde{2}, \widetilde{3}, \widetilde{4}, \widetilde{5}, \widetilde{6}, \widetilde{7}, \widetilde{8}, \widetilde{9}, 1, & i \neq j \\ 1 & i=j\end{cases}
$$

To accumulate the fuzzy weights for each rater group, the fuzzy geometric mean technique was implemented [69]:

$$
\begin{gathered}
\widetilde{r}_{i}=\left(\widetilde{a}_{i 1} \otimes \widetilde{a}_{i 2} \otimes \widetilde{a}_{i 3} \otimes \widetilde{a}_{i 4} \otimes \widetilde{a}_{i 5}\right)^{1 / n}, \\
\widetilde{w}_{i}=\widetilde{r}_{i}\left[\widetilde{r}_{1} \otimes \widetilde{r}_{2} \otimes \widetilde{r}_{3} \otimes \widetilde{r}_{4} \otimes \widetilde{r}_{5}\right]^{-1},
\end{gathered}
$$

where $\widetilde{a}_{i j}$ is the fuzzy comparison value of dimension $i$ to criterion $j$, thus $\widetilde{r}_{i}$ is a geometric mean technique of the fuzzy comparison value of criterion $i$ to each criterion, and $\widetilde{w}_{i}$ is the fuzzy weight of the $i$-th criterion, which is illustrated by a triangular fuzzy number, $\widetilde{w}_{i}=\left(d w_{i}, m w_{i}, h w_{i}\right)$. The $d w_{i}, m w_{i}$, and $h w_{i}$ emblematize the upper, middle, and lower values of the fuzzy weight of the $i$-th dimension.

The consistency ratio (CR) for all pairwise comparison matrices was smaller than 0.1 , which is acceptable to complete the FAHP analysis, as Saaty suggested [56]. The final scores of the proper eigenvectors provide the opportunity to set up a rank order of preferences for the experts of urban transport planning on the system's issues, by analyzing the weights of the previous levels by using the following equation:

$$
\widetilde{w}_{A_{i}}=\frac{\widetilde{w}_{j}}{\widetilde{w}} \frac{\widetilde{w}_{i j}}{\sum_{k=1}^{n} \widetilde{w}_{i k}}=\left(\frac{\widetilde{w}_{j}}{\widetilde{w}} \frac{1}{\sum_{k=1}^{n} \widetilde{w}_{i k}}\right) \widetilde{w}_{i j}
$$

where $j=1, \ldots, \mathrm{m}$ and $\widetilde{w}=\sum_{i=1}^{m} \widetilde{w}_{j} ; \widetilde{w}_{j}>0(j=1, \ldots, \mathrm{m})$ describes the associated weight coordinate from the previous level; $\widetilde{w}_{i j}>0(i=1, \ldots, n)$ is the eigenvector computed from the matrix in the present level; and $\widetilde{w}_{A i}(i=1, \ldots, n)$ is the calculated weight score of the present level's elements.

Where:

$\widetilde{w}_{j}(j=1, \ldots, m)$ is the normalized weight of the first level in our case; and

$\widetilde{w}_{i j}(i=1, \ldots, n)$ is the normalized eigenvector-coordinate of the current level.

\section{Case Study}

The case study described in this article concerns a Latin American city located in Ecuador, which is known as Cuenca. This city is located in the south of Ecuador and is the third-largest city in the country. According to the last census, the city of Cuenca has approximately 505,585 inhabitants distributed as follows: $34 \%$ in the periphery of the city and the remaining $66 \%$ in the urban area. The city has grown in multiple areas according to its economic development, particularly in the city center, which is also classified as a World Heritage Site [70]. The city has a typology that consists of the demarcation of neighborhoods separated by local roads. In addition, Cuenca's central business district maintains the typical characteristics of medium-sized Latin American cities. The city center constitutes the historical and $\mathrm{CBD}$, in contrast to European cities where the historical center and the CBD are different [71]. Therefore, the problems generated in this central area have led to traffic saturation and an increase in the undesirable effects of private vehicles. Local transport planners have implemented a 10-km light rail line that provides transport for residents and tourists to the city center. However, few solutions have been offered for those who use private vehicles and usually come from remote peripheral areas [72]. 
One of these solutions was provided by a study conducted by Ortega et al. [73,74], in which they proposed a set of facilities for a P\&R system. We note that in 2014, a mobility plan was developed to establish more adequate transport policies for the sustainable development of the city [75]. One of them is a parking system. For a better understanding of the city, the 15 zones that compose the city of Cuenca (designated from 1 to 15 ) are presented, as well as the proposed P\&R system (designated from A to G) and the light rail line (LRT) (see Figure 2).

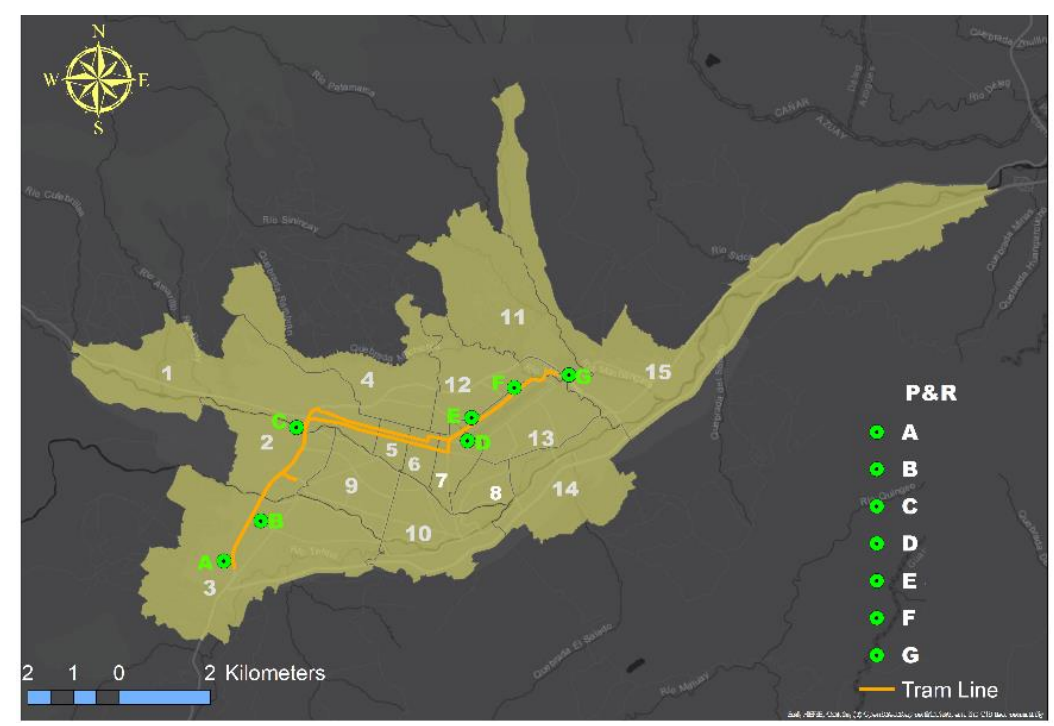

Figure 2. The city of Cuenca Ecuador with the urban areas, Light Rail Line (LRT), and Park and Ride (P\&R).

\section{Results}

In the research, meetings and discussions were held in order to develop a model that may acquire the criteria of the P\&R locations in a simple manner. Figure 3 and Table 2 below exhibits the model. Consequently, the questionnaire survey was conducted in May 2020. The sample of the participants was indiscriminately hand-picked from the park-and-ride planners (experts in the transportation field at the university and municipality) as four women with different age layers who participated in the survey, and six men participated as well. The filling time of the survey was 25 to $30 \mathrm{~min}$ per expert. Altogether, 25 elements of the park and ride (as depicted in Table 2) were assessed to examine the elements of the experts' preferences and attitudes towards $P \& R$ facilities.

Table 2. The applied P\&R facilities' location elements and their short explanations.

\begin{tabular}{|c|c|c|}
\hline Criteria Code & Explanation & Description \\
\hline $\mathrm{C} 1$ & "Distance" & $\begin{array}{l}\text { One of the main parameters for the location of an installation in the } \\
\text { P\&R system is the distance. }\end{array}$ \\
\hline C1.1 & $\begin{array}{l}\text { "Distance from the zones } \\
\text { to the P\&R system." }\end{array}$ & $\begin{array}{l}\text { The city is divided into zones that are the origin of the trips through the } \\
\text { P\&R system. This criterion refers to the distance from the zones to the } \\
\text { P\&R system. }\end{array}$ \\
\hline C1.2 & $\begin{array}{l}\text { "Distance from P\&R } \\
\text { system to Central } \\
\text { Business District." }\end{array}$ & $\begin{array}{l}\text { Among the distance criteria, it is relevant to consider the distance from } \\
\text { the P\&R system to the CBD. }\end{array}$ \\
\hline $\mathrm{C} 2$ & $\begin{array}{l}\text { "Traffic conditions on the } \\
\text { route } \\
\text { (origin-destination)" }\end{array}$ & $\begin{array}{l}\text { The parameter that is considered to locate a facility is the traffic that } \\
\text { exists from the origin to the destination in different periods and through } \\
\text { the combination of two modes of transport that allows the P\&R system } \\
\text { as it is the private vehicle and public transport. }\end{array}$ \\
\hline
\end{tabular}


Table 2. Cont

\begin{tabular}{|c|c|c|}
\hline Criteria Code & Explanation & Description \\
\hline $\mathrm{C} 2.1$ & $\begin{array}{l}\text { "Time of travel by } \\
\text { private car." }\end{array}$ & $\begin{array}{l}\text { This is the first part of the trip through the } P \& R \text { system and represents } \\
\text { the time that a user of a private vehicle may spend on the trip. }\end{array}$ \\
\hline $\mathrm{C} 2.2$ & $\begin{array}{l}\text { "Time of travel by public } \\
\text { transport." }\end{array}$ & $\begin{array}{l}\text { This criterion refers to the second part of the trip that corresponds to the } \\
\text { time that the P\&R system user spends on public transport until reaching } \\
\text { the destination under the conditions of the route. }\end{array}$ \\
\hline $\mathrm{C} 2.3$ & $\begin{array}{l}\text { "Time of travel by P\&R } \\
\text { system." }\end{array}$ & $\begin{array}{l}\text { This criterion refers to the fact that a P\&R system can be considered a } \\
\text { transport mode that allows a modal shift (private vehicle to public } \\
\text { transport); therefore, the travel time through the P\&R system depends } \\
\text { on the location of the facility. }\end{array}$ \\
\hline $\mathrm{C} 3$ & $\begin{array}{l}\text { "Accessibility of public } \\
\text { transport." }\end{array}$ & $\begin{array}{l}\text { This parameter is related to public transport and represents one of the } \\
\text { P\&R systems' goals: the second part of the trip is through public } \\
\text { transport. }\end{array}$ \\
\hline C3.1 & $\begin{array}{l}\text { "Frequency of public } \\
\text { transport operations." }\end{array}$ & $\begin{array}{l}\text { Public transport frequency is a factor that determines how accessible the } \\
\text { system is. }\end{array}$ \\
\hline C 3.2 & $\begin{array}{l}\text { "Transfer time from P\&R } \\
\text { to public transport stop." }\end{array}$ & $\begin{array}{l}\text { A facility is close to the public transport station; therefore, the modal } \\
\text { shift's transfer time ensures accessibility. }\end{array}$ \\
\hline C 3.3 & $\begin{array}{l}\text { "The distance of the P\&R } \\
\text { from the nearest public } \\
\text { transport stop." }\end{array}$ & $\begin{array}{l}\text { The concept of } P \& R \text { location is that the facilities are close to the public } \\
\text { transport stations, the distance from the } P \& R \text { to the public transport } \\
\text { station is a criterion that is considered. }\end{array}$ \\
\hline $\mathrm{C} 4$ & "Transport aspects." & $\begin{array}{l}\text { This criterion refers to the P\&R system in respect of its essential } \\
\text { characteristics within the field of transport. }\end{array}$ \\
\hline C4.1 & $\begin{array}{l}\text { "Reduction of trips by } \\
\text { private car in CBD." }\end{array}$ & $\begin{array}{l}\text { A goal that the P\&R system achieves when it is implemented is that it } \\
\text { reduces private vehicle travel to the CBD. }\end{array}$ \\
\hline C4.2 & $\begin{array}{l}\text { "Increase of demand by } \\
\text { public transport in CBD." }\end{array}$ & $\begin{array}{l}\text { The second part of the trip to reach the destination is made through the } \\
\text { public transport system, and therefore the demand is increased. }\end{array}$ \\
\hline C4.3 & $\begin{array}{l}\text { "Number of public } \\
\text { transport connections } \\
\text { available." }\end{array}$ & $\begin{array}{l}\text { The P\&R system is connected to public transport, and therefore the } \\
\text { connections or lines of public transport is a criterion that allows the } \\
\text { success of the system. }\end{array}$ \\
\hline C4.4 & $\begin{array}{l}\text { "Demand for parking at } \\
\text { a P\&R system." }\end{array}$ & $\begin{array}{l}\text { Demand is the fundamental component to implement any transport } \\
\text { system; therefore, this criterion establishes the demand in the P\&R } \\
\text { system. }\end{array}$ \\
\hline C5 & "Economic" & $\begin{array}{l}\text { The economic analysis as a criterion helps to identify how viable the } \\
\text { project is. }\end{array}$ \\
\hline C5.1 & $\begin{array}{l}\text { "Cost of implementation } \\
\text { for the project." }\end{array}$ & $\begin{array}{l}\text { The criterion refers to the total project cost to implement the P\&R } \\
\text { system. }\end{array}$ \\
\hline C5.2 & "Cost of land use." & $\begin{array}{l}\text { The cost of land use would change the location of the P\&R system. In } \\
\text { some cases, it leads to expropriation in areas where there is already a } \\
\text { previous building. }\end{array}$ \\
\hline C5.3 & $\begin{array}{l}\text { "Cost of the } \\
\text { implementation of the } \\
\text { telecommunication } \\
\text { infrastructure." }\end{array}$ & $\begin{array}{l}\text { The P\&R system needs to report the number of available spots, the } \\
\text { connection with public transport, and the system operation; therefore, a } \\
\text { cost is the implementation of intelligent transportation systems. }\end{array}$ \\
\hline C5.4 & $\begin{array}{l}\text { "Total cost of investment } \\
\text { maintenance." }\end{array}$ & $\begin{array}{l}\text { Maintenance is a cost that leads to ensure that the system is functional } \\
\text { over time. }\end{array}$ \\
\hline C6 & "Environmental" & $\begin{array}{l}\text { This criterion has emerged in recent years as an essential part of } \\
\text { implementing a P\&R system. }\end{array}$ \\
\hline C6.1 & "CO $\mathrm{CO}_{2}$ reduction." & $\begin{array}{l}\text { The } \mathrm{CO}_{2} \text { reduction is based on the criterion that the P\&R system allows } \\
\text { reducing the undesirable effects of the private vehicle through the } \\
\text { decrease of the trips to the CBD. }\end{array}$ \\
\hline C6.2 & "Noise reduction." & $\begin{array}{l}\text { The P\&R system allows the reduction of undesirable effects of the P\&R } \\
\text { system, such as noise reduction. }\end{array}$ \\
\hline C6.3 & $\begin{array}{l}\text { "Area occupied by } \\
\text { existing green areas." }\end{array}$ & $\begin{array}{l}\text { This criterion refers to the fact that most } P \& R \text { systems are implemented } \\
\text { in places that are green areas. This is a reduction in green spaces. }\end{array}$ \\
\hline
\end{tabular}


Further, the P\&R location criteria were structured into a hierarchy, on the one hand, due to the better overview of the researchers and participants, and, on the other hand, because of the requirements of the applied FAHP. The hierarchical structure of the criteria determines the survey process, in which PCs are required from the expert evaluators among the criteria situated in the same branch of the decision criteria tree. Participants have to compare, in a pairwise manner, the criteria of the $P \& R$ facilities as all possible pairs (Figure 3).

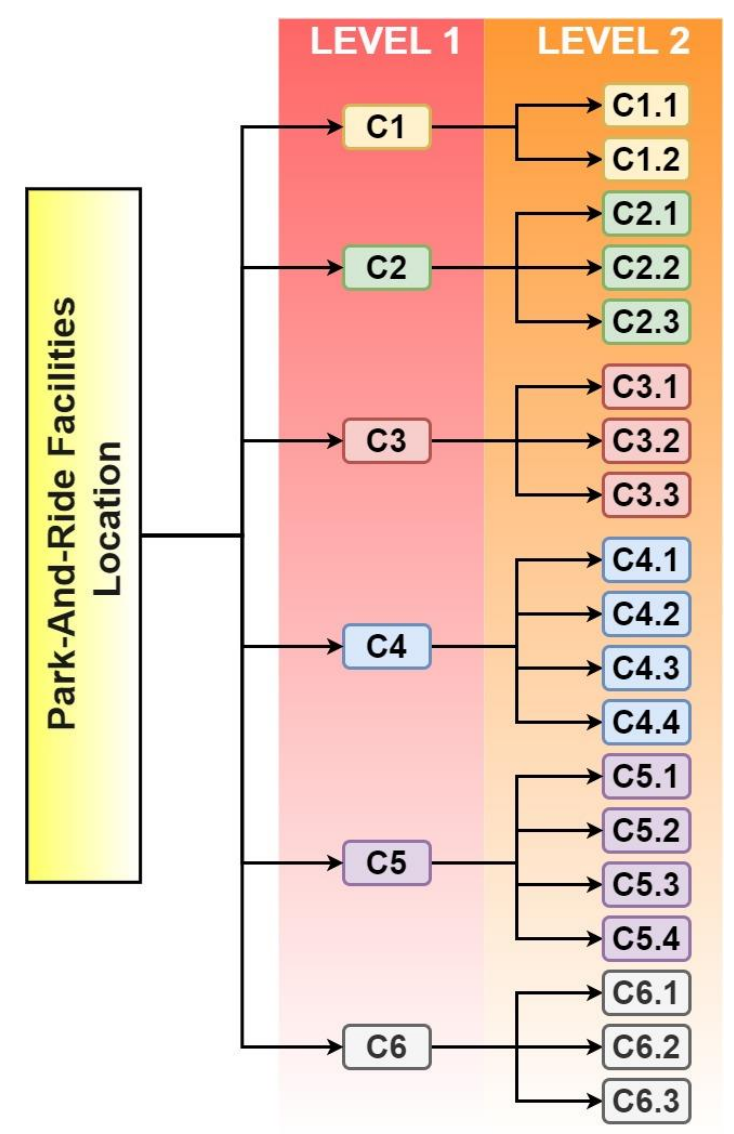

Figure 3. The hierarchical structure of the P\&R facility location.

The typical comparison question is: Compare the relative importance between the "distance-C1" and the "traffic conditions on the route (origin-destination)-C2", with respect to park and ride facilities.

Having gained all scores from the evaluators, following the fuzzy AHP methodology, fuzzy PCs have to be created for all branches of the decision structure, as demonstrated below (Tables 3-9), where the results are aggregated for all evaluators. As shown in the tables below, the fuzzy weight scores of all criteria in all levels express three different scenarios as minimum, medium, and maximum values. A score below 1 indicates real evaluations between zero (expressing a neutral relation between the two decision criteria) and 1, which means a slight superiority of one criterion over another and so forth. 
Table 3. Final aggregated fuzzy comparison matrix $(6 \times 6)$ for the main criteria in level 1 .

\begin{tabular}{|c|c|c|c|c|c|c|c|c|c|c|c|c|c|c|c|c|c|c|}
\hline & & C1 & & & C2 & & & C3 & & & C4 & & & C5 & & & C6 & \\
\hline C1 & 1 & 1 & 1 & 0.7391 & 0.8511 & 0.9663 & 0.2034 & 0.2269 & 0.2580 & 0.2646 & 0.3020 & 0.3451 & 1.2986 & 1.4777 & 1.6606 & 0.1944 & 0.2154 & 0.2424 \\
\hline $\mathrm{C} 2$ & 1.0348 & 1.1749 & 1.3529 & 1 & 1 & 1 & 0.2820 & 0.3103 & 0.3443 & 0.2696 & 0.2990 & 0.3335 & 0.2907 & 0.3197 & 0.3549 & 0.2869 & 0.3150 & 0.3488 \\
\hline C3 & 3.8763 & 4.4071 & 4.9169 & 2.9044 & 3.2223 & 3.5457 & 1 & 1 & 1 & 2.7121 & 3.0366 & 3.3649 & 2.2264 & 2.5845 & 2.9276 & 3.0695 & 3.4464 & 3.8017 \\
\hline C4 & 2.8977 & 3.3107 & 3.7798 & 2.9987 & 3.3450 & 3.7091 & 0.2972 & 0.3293 & 0.3687 & 1 & 1 & 1 & 1.9225 & 2.1637 & 2.3985 & 0.3086 & 0.3512 & 0.4079 \\
\hline C5 & 0.6022 & 0.6767 & 0.7701 & 2.8179 & 3.1280 & 3.4402 & 0.3416 & 0.3869 & 0.4492 & 0.4425 & 0.4803 & 0.5330 & 1 & 1 & 1 & 0.2646 & 0.3020 & 0.3451 \\
\hline C6 & 4.1249 & 4.6434 & 5.1435 & 2.8666 & 3.1748 & 3.4855 & 0.2630 & 0.2902 & 0.3258 & 2.4518 & 2.8470 & 3.2402 & 2.8977 & 3.3107 & 3.7798 & 1 & 1 & 1 \\
\hline
\end{tabular}

Table 4. Final aggregated fuzzy comparison matrix $(4 \times 4)$ for the sub-criteria in level 2 (transport aspects branch).

\begin{tabular}{|c|c|c|c|c|c|c|c|c|c|c|c|c|}
\hline & \multicolumn{3}{|c|}{ C4.1 } & \multicolumn{3}{|c|}{ C4.2 } & \multicolumn{3}{|c|}{ C4.3 } & \multicolumn{3}{|c|}{ C4.4 } \\
\hline C4.1 & 1 & 1 & 1 & 0.5627 & 0.6609 & 0.7736 & 1.0428 & 1.2222 & 1.4142 & 4.7524 & 5.7932 & 6.8220 \\
\hline C 4.2 & 1.2927 & 1.5131 & 1.7771 & 1 & 1 & 1 & 1.3783 & 1.4798 & 1.5874 & 3.2226 & 3.8027 & 4.4302 \\
\hline C 4.3 & 0.7071 & 0.8182 & 0.9590 & 0.6300 & 0.6758 & 0.7255 & 1 & 1 & 1 & 1.3991 & 1.7180 & 2.0829 \\
\hline C4.4 & 0.1466 & 0.1726 & 0.2104 & 0.2257 & 0.2630 & 0.3103 & 0.4801 & 0.5821 & 0.7148 & 1 & 1 & 1 \\
\hline
\end{tabular}

Table 5. Final aggregated fuzzy comparison matrix $(4 \times 4)$ for the sub-criteria in level 2 (economic branch).

\begin{tabular}{|c|c|c|c|c|c|c|c|c|c|c|c|c|}
\hline & \multicolumn{3}{|c|}{ C5.1 } & \multicolumn{3}{|c|}{ C5.2 } & \multicolumn{3}{|c|}{ C5.3 } & \multicolumn{3}{|c|}{ C5.4 } \\
\hline C5.1 & 1 & 1 & 1 & 0.6310 & 0.6444 & 0.6598 & 1.5157 & 1.5518 & 1.5849 & 0.6310 & 0.6893 & 0.7579 \\
\hline C5.2 & 1.5157 & 1.5518 & 1.5849 & 1 & 1 & 1 & 1.2457 & 1.4310 & 1.6345 & 1.7653 & 2.0362 & 2.3199 \\
\hline C5.3 & 0.6310 & 0.6444 & 0.6598 & 0.6118 & 0.6988 & 0.8027 & 1 & 1 & 1 & 1.2723 & 1.3933 & 1.5157 \\
\hline C5.4 & 1.3195 & 1.4509 & 1.5849 & 0.4310 & 0.4911 & 0.5665 & 0.6598 & 0.7177 & 0.7860 & 1 & 1 & 1 \\
\hline
\end{tabular}

Table 6. Final aggregated fuzzy comparison matrix $(3 \times 3)$ for the sub-criteria in level 2 (traffic conditions on the route (origin destination) branch).

\begin{tabular}{cccccccccc}
\hline & \multicolumn{3}{c}{ C2.1 } & \multicolumn{3}{c}{ C2.2 } & & \multicolumn{3}{c}{ C2.3 } \\
\hline $\mathbf{C 2 . 1}$ & 1 & 1 & 1 & 0.1987 & 0.2329 & 0.2894 & 0.2106 & 0.2506 \\
$\mathbf{C} 2.2$ & 3.4553 & 4.2931 & 5.0316 & 1 & 1 & 1 & 0.4928 & 0.5643 & 0.6499 \\
$\mathbf{C 2 . 3}$ & 3.1295 & 3.9910 & 4.7484 & 1.5387 & 1.7720 & 2.0294 & 1 & 1 & 1 \\
\hline
\end{tabular}


Table 7. Final aggregated fuzzy comparison matrix $(3 \times 3)$ for the sub-criteria in level 2 (accessibility of the public transport branch).

\begin{tabular}{ccccccccccc}
\hline & \multicolumn{3}{c}{ C3.1 } & \multicolumn{3}{c}{ C3.2 } & \multicolumn{3}{c}{ C3.3 } \\
\hline C3.1 & 1 & 1 & 1 & 4.8914 & 6.0000 & 7.0681 & 2.7865 & 3.4713 & 4.2823 \\
C3.2 & 0.1415 & 0.1667 & 0.2044 & 1 & 1 & 1 & 0.3432 & 0.4251 & 0.5493 \\
C3.3 & 0.2335 & 0.2881 & 0.3589 & 1.8206 & 2.3522 & 2.9137 & 1 & 1 & 1 \\
\hline
\end{tabular}

Table 8. Final aggregated fuzzy comparison matrix $(3 \times 3)$ for the sub-criteria in level 2 (environmental branch).

\begin{tabular}{cccccccccc}
\hline & \multicolumn{3}{c}{ C6.1 } & \multicolumn{3}{c}{ C6.2 } & \multicolumn{3}{c}{ C6.3 } \\
\hline C6.1 & 1 & 1 & 1 & 3.3220 & 3.6889 & 4.0357 & 3.3220 & 3.6889 & 4.0357 \\
C6.2 & 0.2478 & 0.2711 & 0.3010 & 1 & 1 & 1 & 1.8644 & 2.0396 & 2.2209 \\
C6.3 & 0.2478 & 0.2711 & 0.3010 & 0.4503 & 0.4903 & 0.5364 & 1 & 1 & 1 \\
\hline
\end{tabular}

Afterward, the final scores were computed by conducting the eigenvector method of the AHP technique. Deriving eigenvector scores and then computing the weight scores enabled us to determine the importance of each element in the decision structure in the decision, in our case, in the location of the facilities of the P\&R system of the respondents. The higher score means the higher importance attached to each element. The order of scores implies a ranking of importance, which is significant support of the P\&R location for transport planners. The priority order of different criteria in park-and-ride facilities in terms of their development is presented in Tables 9 and 10.

Table 9. The weight scores for park-and-ride facilities' main criteria in level 1.

\begin{tabular}{ccc}
\hline Criteria & Weight & Rank \\
\hline C1 & 0.0704 & 5 \\
C2 & 0.0645 & 6 \\
C3 & 0.3667 & 1 \\
C4 & 0.1621 & 3 \\
C5 & 0.0961 & 4 \\
C6 & 0.2527 & 2 \\
\hline
\end{tabular}

Table 10. The weight scores for park-and-ride facilities' sub-criteria in level 2.

\begin{tabular}{cccccc}
\hline Main Criteria & Sub-Criteria & Local Weight & Rank & Global Weight & Rank \\
\hline \multirow{2}{*}{ C1 } & C1.1 & 0.8294 & 1 & 0.0584 & 5 \\
& C1.2 & 0.1706 & 2 & 0.0120 & 18 \\
\hline \multirow{2}{*}{ C2 } & C2.1 & 0.1106 & 3 & 0.0071 & 19 \\
& C2.2 & 0.3738 & 2 & 0.0241 & 13 \\
& C2.3 & 0.5334 & 1 & 0.0344 & 11 \\
\hline \multirow{3}{*}{ C3 } & C3.1 & 0.6957 & 1 & 0.2551 & 1 \\
& C3.2 & 0.1063 & 3 & 0.0390 & 8 \\
& C3.3 & 0.2232 & 2 & 0.0819 & 3 \\
\hline \multirow{3}{*}{ C4 } & C4.1 & 0.3267 & 2 & 0.0530 & 7 \\
& C4.2 & 0.3794 & 1 & 0.0615 & 4 \\
& C4.3 & 0.2197 & 3 & 0.0356 & 9 \\
& C4.4 & 0.0906 & 4 & 0.0147 & 17 \\
\hline \multirow{2}{*}{ C5 } & C5.1 & 0.2228 & 2 & 0.0214 & 14 \\
& C5.2 & 0.3569 & 1 & 0.0343 & 12 \\
& C5.3 & 0.2180 & 3 & 0.0209 & 15 \\
C6 & C5.4 & 0.2076 & 4 & 0.0200 & 16 \\
& C6.1 & 0.6445 & 1 & 0.1628 & 2 \\
& C6.2 & 0.2225 & 2 & 0.0562 & 6 \\
& C6.3 & 0.1385 & 3 & 0.0350 & 10 \\
\hline
\end{tabular}




\section{Discussion}

The survey conducted on transport planners that work in the municipality and local universities about the location of the facilities in the P\&R system allowed evaluating fundamentally what the planners take into account when locating a facility. Using this evaluation, it is possible to determine which criteria they consider most relevant, as well as that the planners agree with the goal of the P\&R when it is applied in an urban environment.

According to the criteria chosen by the transport planners regarding the location of the P\&R system's facilities, the following criterion classification order is presented. The most important element for the location of P\&R facilities is C3 "accessibility of public transport" (see Figure 4), which is interpreted by the planners as a top-ranking criterion since the P\&R system in its location concept requires to be located close to public transport stations and therefore its accessibility is already guaranteed. However, the new idea arises to encourage the modal shift from private to public transport in medium-sized Latin American cities in which the P\&R system has not been sufficiently promoted as a modal shift location; this criterion must be extended by the planners, making it more relevant to cities that have initiated or wish to implement the P\&R system in Cuenca. A less critical criterion for planners is C6 "environmental", as it is considered that its location could diminish the undesirable effects caused by a private vehicle. However, based on recent research [76], it is a fact that P\&R can reduce such undesirable effects and should be included in environmental policies in mobility plans, which includes reducing pollution. Subsequently, C4 refers to some aspects of transport, in general to categorize the P\&R system as a transport mode more related to demand, its capacity, and the interaction with other transport modes, such as public transport. For instance, the number of transport lines connected to the P\&R system, which is defined as the accessibility. The C5 "economic" is a mid-range consideration for planners throughout to develop a project not only concerning the $P \& R$ system. Its importance is related to the costs of the project and is easily explained because the transportation planners consider the viability of a project in terms of its costs; thus, the location depends highly on the budget, mainly because local authorities develop these projects. Continuing with the lower-rank criterion is the C2 "traffic conditions on the route (origin-destination)", since, as has been widely mentioned, the main objective of the $P \& R$ system is to reduce private vehicle trips to the CBD or in the urban environment of a city. We mentioned that it is the traffic on the P\&R route (percentage of trips by private vehicles and a percentage of trips by public transport). This means that transportation planners do not consider the traffic on the $P \& R$ route as a problem that affects the location of the facilities. The traffic is not essential in the second part of the trip because the users of the P\&R system could use direct or exclusive public transport lines to the CBD. In our case, this is an LRT system that does not circulate along with the city traffic, thus allowing the users of private vehicles to choose the use of a P\&R system to arrive at their destination and not to deal with the traffic conditions. The distance $\mathrm{C} 1$ is a criterion that transportation planners consider more important than the previous criterion because the distance makes the planned transportation line longer if the P\&R system is situated more distant from the CBD. 


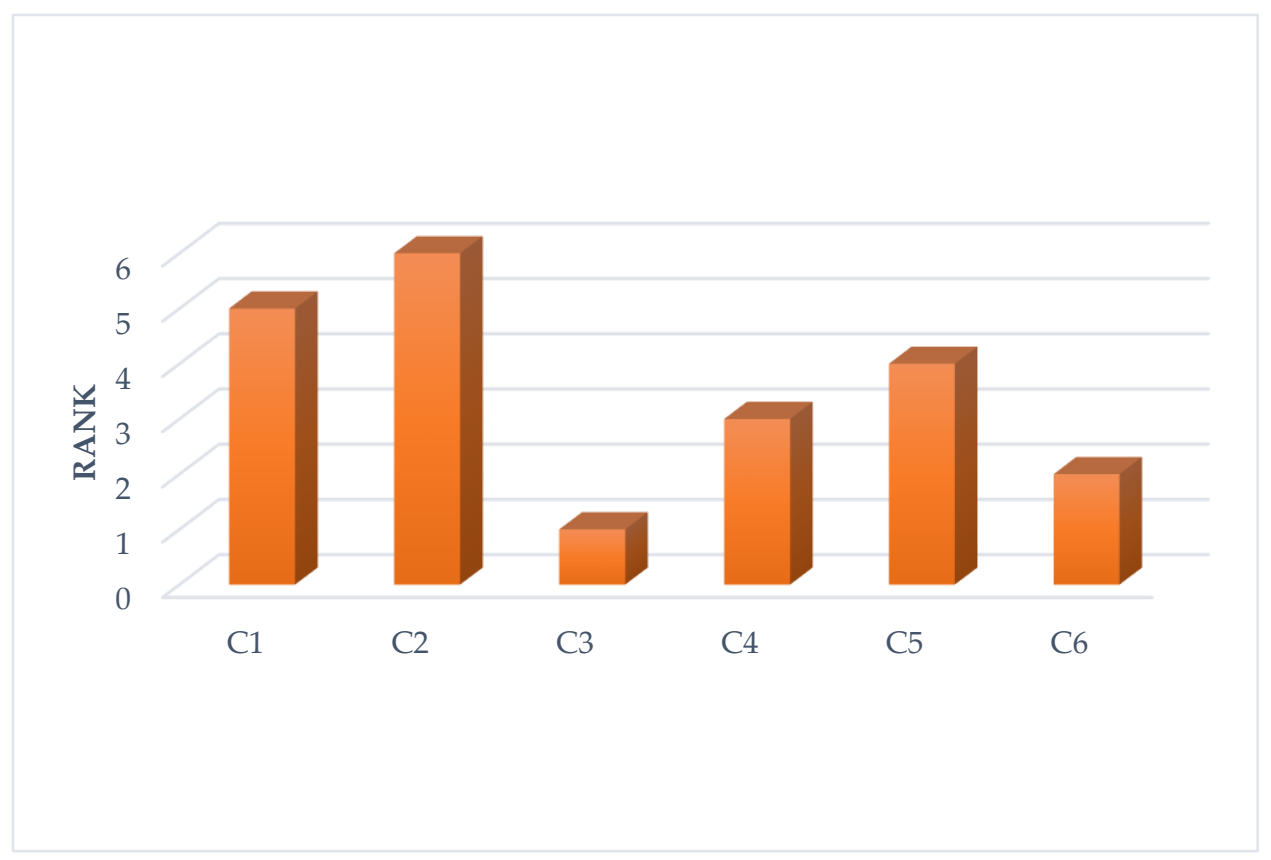

Figure 4. Priority ranking of the main criteria.

In order to give a more precise explanation of level two and according to the high number of sub-criteria established, a classification of importance was made: Most important, mid-level important, and low-level important, e.g., most important $<6$, mid-level important 6-12, $>12$ low-level important. Each principal criterion is described with its sub-criteria in order of classification, and a second part describes all the sub-criteria and their interaction with each other.

For example, the distance criterion $\mathrm{C} 1$ and its sub-criteria $\mathrm{C} 1.1$ is ranked 5, and $\mathrm{C} 1.2$ is ranked 18 . This means that for transport planners, the distance traveled by private vehicles is more important than the distance of the second part of the journey, which is by public transport. It is because a potential user who has made most of his/her trip in a private vehicle hardly uses the P\&R system to complete his/her trip. Therefore, location becomes crucial to make the journey through a P\&R system. According to criterion $\mathrm{C} 2$, there is the following order of importance of the sub-criteria chosen by the transport planners: C2.3, C2.2, and C1.1. The reason is that the traffic or total time when using the P\&R system is the most relevant because the success of any transport system depends on the traffic conditions or the time that it takes to complete the trip. The criterion $\mathrm{C} 3$ and its sub-criteria in order of importance are C3.1, C3.3, and C3.2. Within this main criterion, two of its sub-criteria are relevant for the location of the facilities of a P\&R system. For example, the frequency of the public transport system ensures the success of the $P \& R$ system. This is particularly important because transport planners determine that the $P \& R$ system is strongly linked to public transport. The success or decline of the system depends on the service coverage for the second part of the journey. Distance and travel time are also relevant factors, and the concept of $P \& R$ ensures that the $P \& R$ system facilities are located close to public transport stations. Criterion $\mathrm{C} 4$ and its sub-criteria are classified as follows in order of importance: $\mathrm{C} 4.2, \mathrm{C} 4.1, \mathrm{C} 4.3$, and C4.4. In other words, the demand produced by the P\&R system is covered by a larger number of transport routes.

Consequently, the demand produced by the $P \& R$ system is covered by a larger number of transport routes. Besides, the demand for both the public transport system and the P\&R system are aspects that must be considered when locating the P\&R system facilities. Criterion $C 5$ and its sub-criteria in the range of importance: C5.2, C5.1, C5.3, and C5.4, and the difference between them is not substantial. Transport planners consider the technical criteria related to the P\&R system to be more significant than those associated with the cost sub-criteria. The environmental criterion C6 in the order of importance in the sub-criteria is as follows: C6.1, C6.2, and C6.3, since the P\&R system has been identified as a tool 
that allows the reduction of $\mathrm{CO}_{2}$ as a result of the reduction of undesirable trips to the city center caused by the use of private vehicles. However, concerning noise reduction, it is not considered relevant, because currently there is no strong evidence of noise reduction when a $P \& R$ system is implemented, and concerning criterion C6.3, using the assumption that green areas can be reduced by implementing the P\&R system; although, the P\&R system can be developed in combination with green spaces.

For level 2, the most relevant criterion to be taken into account is $\mathrm{C} 3.1$, which refers to the frequency of public transport that could be optimized, since this would promote the shift from the private vehicle to public transport. Besides, the use of intelligent transport systems (ITSs) that allow the coordination of the connection between the P\&R system and the public transport system implies an improvement in the operation of the system (see Figure 5). The following criterion, C6.1, as discussed in detail, helps explain the implementation of a $P \& R$ system, as it could reduce pollution. Cuenca is considered to be a city that generates a high level of pollution in CBD from private vehicles, and planners consider the $\mathrm{P} \& \mathrm{R}$ system as a tool to reduce pollution. The next criterion is $\mathrm{C} 3.3$, which represents what planners already know, in which the location of facilities in a P\&R system is close to public transport stations. In addition, the criteria that planners stipulate as relevant when considering the location of the P\&R system facilities are the set of criteria C4.2, C1.1, and C6.2, which are criteria based on the traditional P\&R system approach, which are relevant to the operation or implementation of the P\&R system. At least in Latin American cities, the P\&R system is relatively new; therefore, the shift from private to public transport and the distance from urban areas (origin) to the facility system (P\&R) has not been extensively studied. Addressing these criteria to cities where the P\&R system has already been applied would help us understand the difference between transport planners' priorities in Latin America and European transport planners. Subsequently, among the 19 sub-criteria, we describe those that planners consider moderate in importance. Thus, the reduction of travel to the CBD represented by criterion C4.1 is for transport planners, which they hope to achieve through various initiatives, such as bicycles. However, the alternative to implement a P\&R system is very useful for those who use private vehicles. In Latin American cities, little scientific evidence has been carried out on the P\&R system as a mode of transport to reduce the percentage of trips to the CBD. It is essential to determine that percentage; thus, the planners could modify the location of the P\&R system facilities to establish which facility reduces most private vehicle trips. Additionally, it is possible to stipulate a set of criteria, C4.3, C6.3, C2.3, and C5.2, as medium importance that involves public transport aspects. These criteria have led to the determination that the $P \& R$ system is studied or known as a system that is part of the transport system and not a system that operates separately. However, the criterion that certainly increases in bigger cities is C2.3, since it allows the P\&R system to be considered as a transport system, as an alternative to a more friendly transport mode. It has been possible to determine a set of criteria considered to be of lower importance, which is the costs of implementation since as it depends on the facility's location, the cost varies. Therefore, criterion C5.2 is identified as the costs represented by land-use when implementing the $P \& R$ system. However, it is important to note that criterion C2.2, which is the time that public transport takes from the P\&R to the CBD, is important for the operation of the system. C5.3 and C5.4 provides a useful approach when transport planners are focused on carrying out a study to implement the P\&R system in a Latin American city. C4.4 is one of the criteria that planners consider to be a technical aspect of any transport system, and it is the demand on the system; the demand is directly related to the facility's location. Besides, criterion C1.2 is one of the less important with C2.1. Both describe the operation of a P\&R system in the first part of the trip made in a private vehicle, and the planners consider the second part of the journey, which is through public transport, as more relevant. In our case, it is by LRT. 


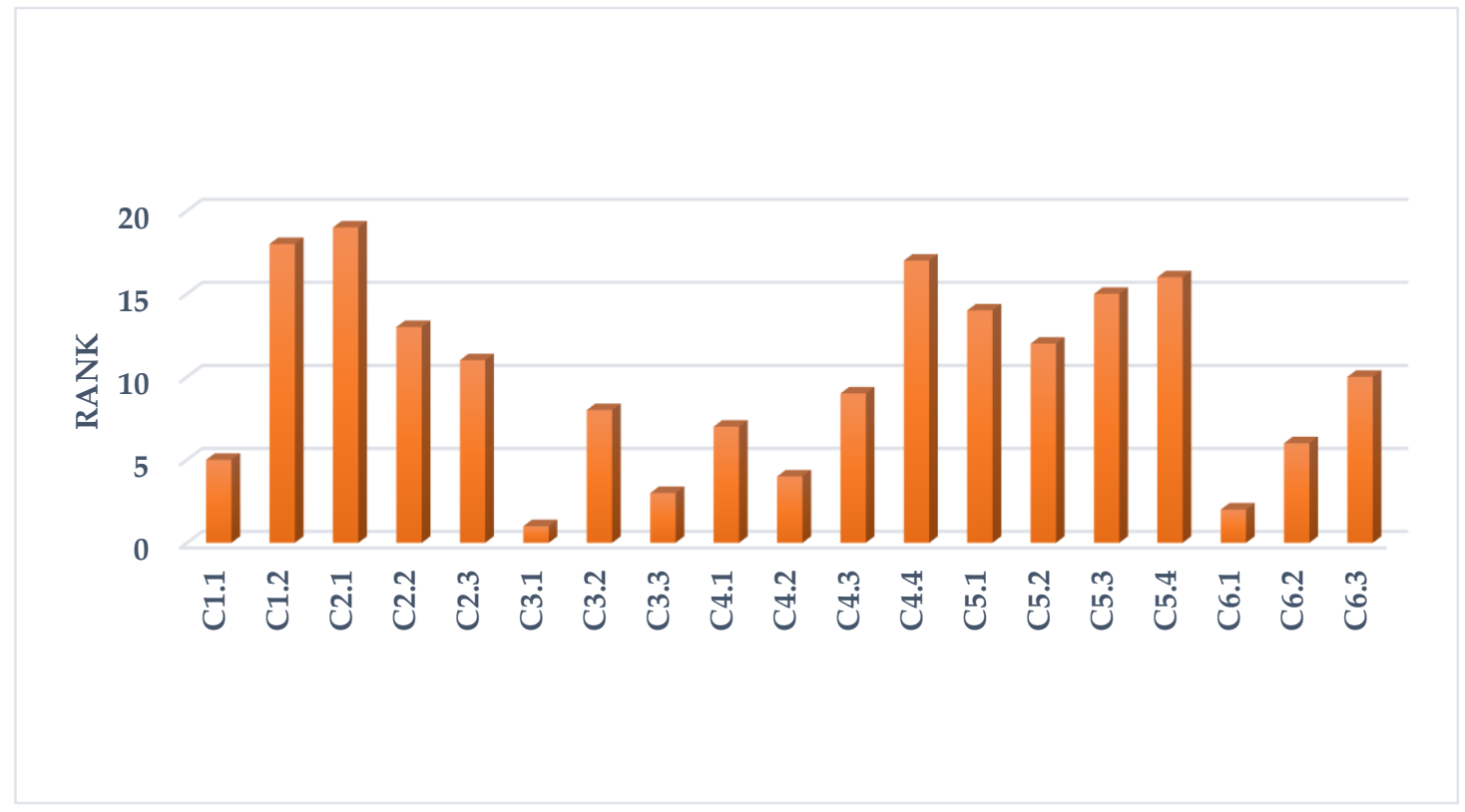

Figure 5. Priority ranking of sub-criteria.

A sensitivity test was applied to all levels. In fact, the scores for the other criteria were adjusted to maintain a value of one for the total weight scores. In the sensitivity analysis, the ranking level was maintained, and the change in ranking was studied according to the ability of the planners to select a criterion. This means that planners select location criteria based on their experience in implementing a P\&R system.

The Cuenca municipality has developed several transport projects, including the implementation of a new transport system, the LRT, which is the most ambitious system presented by the city and is considered a symbolic project. In addition, a mobility plan was developed that considers the parking system in the city.

Our study goes further by considering the P\&R system and which criteria are relevant for medium-sized city planners when they implement the P\&R system. Using the P\&R system, this scientifically proven system reduces trips to the city center and provides incentives for private transport users to switch to more friendly transport modes, such as public transport. One of the most important considerations or criteria is the accessibility of public transport. However, moving to a more critical point from a technical point of view, we can state that it is also necessary to update and inform the authorities of P\&R's purpose, which becomes a fundamental tool within transport planning. This system is relatively new in Latin America. It would be beneficial to apply this same criterion to researchers and local authorities that have already developed the P\&R system and to make a comparison between Latin American and European cities.

\section{Conclusions}

This document aimed to introduce a new approach to determining the criteria of transport planners when establishing a set of $P \& R$ system facilities through a multicriteria decision model (MCDM) that integrates the attributes related to the P\&R system. Since the current study integrated attributes, such as environment and traffic, the usual AHP methodology was selected. The application of the verified model allowed valuable information to be acquired through a survey and then the AHP method was applied, aimed at transport planning specialists, to find out which parameters are taken into account for location.

The results proved to be realistic, reflecting decisions that are taken into consideration by mathematical studies about the variables considered for the location of the P\&R system, such as the cost of implementing a transport project, and the accessibility of public transport. This approach also 
showed that the P\&R system is relatively new in certain Latin American cities and that certain technical aspects taken into consideration as part of the scientific evidence of the P\&R system to reduce traffic are secondary. For example, a new approach would be to apply this system to cities that have already had a P\&R system for several years, so that these criteria can be seen to vary.

The presented model can be suitable for the study of different transport problems in cities of any magnitude. However, it should be noted that, given various PCs, the survey process is considerably demanding and needs a considerable amount of time and effort on the part of the evaluators; thus, collecting the responses of several interviewed transport planners could be problematic. This is a limitation of the current model, and therefore, for a larger sample size, an alternative may be more convenient than the AHP method.

Furthermore, there are more new types of AHP models listed in the literature, for instance, those called fuzzy models and models combined with other MCDM techniques (e.g., TOPSIS, machine learning, ELECTREE). Besides, in the future, the combination of this model with another large group of models, for example, the optimization, geographical, and mathematical models, for the location of P\&R system facilities could lead to a much more efficient study of the criteria that transport planners take as a priority for the location of facilities of the P\&R system.

Author Contributions: Formal analysis, J.O. and S.M.; Investigation, J.O., J.T., T.P. and S.D.; Methodology, J.O.; Project administration, J.T., T.P. and S.D.; Resources, J.O.; Software, S.M.; Supervision, S.M.; Visualization, S.D.; Writing-original draft, S.M., J.O.; Writing-review \& editing, J.O. All authors have read and agreed to the published version of the manuscript.

Funding: This research received no external funding.

Acknowledgments: We are grateful to the Cuenca Municipality, which has provided the Sustainable Mobility Plan.

Conflicts of Interest: The authors declare no conflicts of interest.

\section{References}

1. European Commission. A Concept for Sustainable Urban Mobility Plans. Eur. Union 2013, 1, 153.

2. Pitsiava-Latinopoulou, M.; Basbas, S.; Papoutsis, K.; Sdoukopoulos, E. Parking Policies for Supporting Sustainable Mobility. Procedia Soc. Behav. Sci. 2012, 48, 897-906. [CrossRef]

3. Antolin, G.; Ibeas, A.; Alonso, B.; Dell'Olio, L. Modelling parking behaviour considering users heterogeneities. Transp. Policy 2018, 67, 23-30. [CrossRef]

4. Saharidis, G.K.; Rizopoulos, D.; Fragkogios, A.; Chatzigeorgiou, C. A hybrid approach to the problem of journey planning with the use of mathematical programming and modern techniques. Transp. Res. Procedia 2017, 24, 401-409. [CrossRef]

5. Rizopoulos, D.; Saharidis, G.K.D. Generic approaches for the rescheduling of public transport services. Energy Syst. 2020, 1-30. [CrossRef]

6. Antolín, G.; Alonso, B.; Cordera, R.; Dell'Olio, L. The Effect of Introducing Parking Policies on Managing Mobility to Beaches in Touristic Coastal Towns. Sustainability 2019, 11, 3528. [CrossRef]

7. Yashiro, R.; Kato, H. Success factors in the introduction of an intermodal passenger transportation system connecting high-speed rail with intercity bus services. Case Stud. Transp. Policy 2019, 7, 708-717. [CrossRef]

8. Moeinaddini, M.; Asadi-Shekari, Z.; Shah, M.Z. Analysing the Relationship between Park-and-Ride Facilities and Private Motorised Trips Indicators. Arab. J. Sci. Eng. 2014, 39, 3481-3488. [CrossRef]

9. Olsson, A.-L.L. Factors That Influence Choice of Travel Mode in Major Urban Areas: The Attractiveness of Park $\mathcal{E}$ Ride; KTH Royal Institute of Technology: Stockholm, Sweden, 2003.

10. Hounsell, N.; Shrestha, B.; Piao, J. Enhancing Park and Ride with access control: A case study of Southampton. Transp. Policy 2011, 18, 194-203. [CrossRef]

11. Ortega, J.; Hamadneh, J.; Esztergar-Kiss, D.; Tóth, J. Simulation of the Daily Activity Plans of Travelers Using the Park-and-Ride System and Autonomous Vehicles: Work and Shopping Trip Purposes. Appl. Sci. 2020, 10, 2912. [CrossRef]

12. Ortega, J.; Tóth, J.; Péter, T.; Moslem, S. An Integrated Model of Park-And-Ride Facilities for Sustainable Urban Mobility. Sustainability 2020, 12, 4631. [CrossRef] 
13. Rizopoulos, D.; Esztergar-Kiss, D. A Method for the Optimization of Daily Activity Chains Including Electric Vehicles. Energies 2020, 13, 906. [CrossRef]

14. Wang, J.Y.; Yang, H.; Lindsey, R. Locating and pricing park-and-ride facilities in a linear monocentric city with deterministic mode choice. Transp. Res. Part B Methodol. 2004, 38, 709-731. [CrossRef]

15. Parkhurst, G. Park and ride: Could it lead to an increase in car traffic? Transp. Policy 1995, 2, 15-23. [CrossRef]

16. Dickins, I.S.J. Park and ride facilities on light rail transit systems. Transportation 1991, 18, 23-36. [CrossRef]

17. Liu, T.-L.; Huang, H.-J.; Yang, H.; Zhang, X. Continuum modeling of park-and-ride services in a linear monocentric city with deterministic mode choice. Transp. Res. Part B Methodol. 2009, 43, 692-707. [CrossRef]

18. Farhan, B.; Murray, A.T. A GIS-Based Approach for Delineating Market Areas for Park and Ride Facilities. Trans. GIS 2005, 9, 91-108. [CrossRef]

19. Williams, R. Oxford's park-and-ride system. Proc. Inst. Civ. Eng. Munic. Eng. 1999, 133, 127-135. [CrossRef]

20. Song, Z.; He, Y.; Zhang, L. Integrated planning of park-and-ride facilities and transit service. Transp. Res. Part C Emerg. Technol. 2017, 74, 182-195. [CrossRef]

21. Zhou, Y.; Li, Y.; Hao, M.; Yamamoto, T.; Zhou, L.; Hao, A. System of Shared Autonomous Vehicles Combined with Park-And-Ride in Residential Areas. Sustainability 2019, 11, 3113. [CrossRef]

22. Chen, X.; Kim, I. Modelling Rail-Based Park and Ride with Environmental Constraints in a Multimodal Transport Network. J. Adv. Transp. 2018, 2018, 1-15. [CrossRef]

23. Horner, M.W.; Grubesic, T.H. A GIS-based planning approach to locating urban rail terminals. Transportation 2001, 28, 55-77. [CrossRef]

24. Du, B.; Wang, D.Z.W. Continuum modeling of park-and-ride services considering travel time reliability and heterogeneous commuters-A linear complementarity system approach. Transp. Res. Part E Logist. Transp. Rev. 2014, 71, 58-81. [CrossRef]

25. Ni, A.; Lin, X.; Luo, J. Stochastic Traffic Assignment Model Considering Park \& Ride Network and Travel Time Reliability. In Lecture Notes in Electrical Engineering; Springer: Singapore, 2018; pp. 873-886.

26. Cavadas, J.; Antunes, A.P. An optimization model for integrated transit-parking policy planning. Transportation 2018, 46, 1867-1891. [CrossRef]

27. Cavadas, J.; Antunes, A.P. Optimization-based study of the location of park-and-ride facilities. Transp. Plan. Technol. 2019, 42, 201-226. [CrossRef]

28. Aros-Vera, F.; Marianov, V.; Mitchell, J.E. p-Hub approach for the optimal park-and-ride facility location problem. Eur. J. Oper. Res. 2013, 226, 277-285. [CrossRef]

29. Holguín-Veras, J.; Yushimito, W.; Aros-Vera, F.; Reilly, J. User rationality and optimal park-and-ride location under potential demand maximization. Transp. Res. Part B Methodol. 2012, 46, 949-970. [CrossRef]

30. Holguín-Veras, J.; Reilly, J.; Aros-Vera, F.; Yushimito, W.; Isa, J. Park-and-Ride Facilities in New York City. Transp. Res. Rec. J. Transp. Res. Board 2012, 2276, 123-130. [CrossRef]

31. Farhan, B.; Murray, A.T. Distance decay and coverage in facility location planning. Ann. Reg. Sci. 2006, 40, 279-295. [CrossRef]

32. Farhan, B.; Murray, A.T. Siting park-and-ride facilities using a multi-objective spatial optimization model. Comput. Oper. Res. 2008, 35, 445-456. [CrossRef]

33. Shafiei, S.; Vaelizadeh, R.; Bertrand, F.; Ansari, M. Evaluating and Ranking of Travel Mode in Metropolitan a Transportation Approach. Civ. Eng. J. 2018, 4, 1303. [CrossRef]

34. Dudek, M.; Solecka, K.; Richter, M. A multi-criteria appraisal of the selection of means of urban passenger transport using the Electre and AHP methods. Czas. Tech. 2018, 6, 79-93. [CrossRef]

35. Moslem, S.; Duleba, S. Application of AHP for evaluating passenger demand for public transport improvements in Mersin, Turkey. Pollack Period. 2018, 13, 67-76. [CrossRef]

36. Moslem, S.; Ghorbanzadeh, O.; Blaschke, T.; Duleba, S. Analysing Stakeholder Consensus for a Sustainable Transport Development Decision by the Fuzzy AHP and Interval AHP. Sustainability 2019, 11, 3271. [CrossRef]

37. Moslem, S.; Gul, M.; Farooq, D.; Celik, E.; Ghorbanzadeh, O.; Blaschke, T. An Integrated Approach of Best-Worst Method (BWM) and Triangular Fuzzy Sets for Evaluating Driver Behavior Factors Related to Road Safety. Mathematics 2020, 8, 414. [CrossRef]

38. Moslem, S.; Alkharabsheh, A.; Ismael, K.; Duleba, S. An Integrated Decision Support Model for Evaluating Public Transport Quality. Appl. Sci. 2020, 10, 4158. [CrossRef]

39. Duleba, S.; Moslem, S. Examining Pareto optimality in analytic hierarchy process on real Data: An application in public transport service development. Expert Syst. Appl. 2019, 116, 21-30. [CrossRef] 
40. Jin, H.; Zhang, M.; Yuan, Y. Analytic Network Process-Based Multi-Criteria Decision Approach and Sensitivity Analysis for Temporary Facility Layout Planning in Construction Projects. Appl. Sci. 2018, 8, 2434. [CrossRef]

41. Hervás-Peralta, M.; Poveda-Reyes, S.; Molero, G.D.; Santarremigia, F.E.; Pastor-Ferrando, J.-P. Improving the Performance of Dry and Maritime Ports by Increasing Knowledge about the Most Relevant Functionalities of the Terminal Operating System (TOS). Sustainability 2019, 11, 1648. [CrossRef]

42. Ligmann-Zielinska, A.; Jankowski, P. Spatially-explicit integrated uncertainty and sensitivity analysis of criteria weights in multicriteria land suitability evaluation. Environ. Model. Softw. 2014, 57, 235-247. [CrossRef]

43. Ghorbanzadeh, O.; Feizizadeh, B.; Blaschke, T. Multi-criteria risk evaluation by integrating an analytical network process approach into GIS-based sensitivity and uncertainty analyses. Geomatic. Nat. Hazards Risk 2017, 9, 127-151. [CrossRef]

44. Meena, S.R.; Ghorbanzadeh, O.; Blaschke, T. A Comparative Study of Statistics-Based Landslide Susceptibility Models: A Case Study of the Region Affected by the Gorkha Earthquake in Nepal. ISPRS Int. J. Geo Inf. 2019, 8, 94. [CrossRef]

45. Ha, M.H.; Yang, Z.; Heo, M.W. A New Hybrid Decision Making Framework for Prioritising Port Performance Improvement Strategies. Asian J. Shipp. Logist. 2017, 33, 105-116. [CrossRef]

46. Prasetyo, D.H.; Mohamad, J.; Fauzi, R. A GIS-based multi-criteria decision analysis approach for public school site selection in Surabaya, Indonesia. Geomatica 2018, 72, 69-84. [CrossRef]

47. Grošelj, P.; Stirn, L.Z. Evaluation of several approaches for deriving weights in fuzzy group analytic hierarchy process. J. Decis. Syst. 2018, 27, 217-226. [CrossRef]

48. Pourghasemi, H.R.; Pradhan, B.; Gokceoglu, C. Application of fuzzy logic and analytical hierarchy process (AHP) to landslide susceptibility mapping at Haraz watershed, Iran. Nat. Hazards 2012, 63, 965-996. [CrossRef]

49. Fan, G.; Zhong, D.; Yan, F.; Yue, P. A hybrid fuzzy evaluation method for curtain grouting efficiency assessment based on an AHP method extended by D numbers. Expert Syst. Appl. 2016, 44, 289-303. [CrossRef]

50. Nazmfar, H.; Saredeh, A.; Eshgi, A.; Feizizadeh, B. Vulnerability evaluation of urban buildings to various earthquake intensities: A case study of the municipal zone 9 of Tehran. Hum. Ecol. Risk Assess. Int. J. 2019, 25, 455-474. [CrossRef]

51. Razandi, Y.; Pourghasemi, H.R.; Neisani, N.S.; Rahmati, O. Application of analytical hierarchy process, frequency ratio, and certainty factor models for groundwater potential mapping using GIS. Earth Sci. Inform. 2015, 8, 867-883. [CrossRef]

52. Ghorbanzadeh, O.; Moslem, S.; Blaschke, T.; Duleba, S. Sustainable Urban Transport Planning Considering Different Stakeholder Groups by an Interval-AHP Decision Support Model. Sustainability 2018, 11, 9. [CrossRef]

53. Cabrera-Barona, P.; Ghorbanzadeh, O. Comparing Classic and Interval Analytical Hierarchy Process Methodologies for Measuring Area-Level Deprivation to Analyze Health Inequalities. Int. J. Environ. Res. Public Health 2018, 15, 140. [CrossRef]

54. Fierek, S.; Bieńczak, M.; Zmuda-Trzebiatowski, P. Multiple criteria evaluation of P\&R lots location. Transp. Res. Procedia 2020, 47, 489-496.

55. Lakusic, S.; Barauskas, A.; Mateckis, K.J.; Palevičius, V.; Antucheviciene, J. Ranking conceptual locations for a park-and-ride parking lot using EDAS method. J. Croat. Assoc. Civ. Eng. 2018, 70, 975-983. [CrossRef]

56. Wind, Y.; Saaty, T.L. Marketing Applications of the Analytic Hierarchy Process. Manag. Sci. 1980, 26, 641-658. [CrossRef]

57. Duleba, S.; Mishina, T.; Shimazaki, Y. A dynamic analysis on public bus transport's supply quality by using AHP. Transportation 2012, 27, 268-275. [CrossRef]

58. Balaji, M.; Santhanakrishnan, S.; Dinesh, S.N. An Application of Analytic Hierarchy Process in Vehicle Routing Problem. Period. Polytech. Transp. Eng. 2018, 47, 196-205. [CrossRef]

59. Duleba, S.; Moslem, S. Sustainable Urban Transport Development with Stakeholder Participation, an AHP-Kendall Model: A Case Study for Mersin. Sustainability 2018, 10, 3647. [CrossRef]

60. Farooq, D.; Moslem, S. Evaluation and Ranking of Driver Behavior Factors Related to Road Safety by Applying Analytic Network Process. Period. Polytech. Transp. Eng. 2019, 48, 189-195. [CrossRef] 
61. Kumar, A.; Pal, A.; Vohra, A.; Gupta, S.; Manchanda, S.; Dash, M.K. Construction of capital procurement decision making model to optimize supplier selection using Fuzzy Delphi and AHP-DEMATEL. Benchmarking Int. J. 2018, 25, 1528-1547. [CrossRef]

62. Abastante, F.; Corrente, S.; Greco, S.; Ishizaka, A.; Lami, I.M. Choice architecture for architecture choices: Evaluating social housing initiatives putting together a parsimonious AHP methodology and the Choquet integral. Land Use Policy 2018, 78, 748-762. [CrossRef]

63. Haghighathoseini, A.; Bobarshad, H.; Saghafi, F.; Rezaei, M.S.; Bagherzadeh, N. Hospital enterprise Architecture Framework (Study of Iranian University Hospital Organization). Int. J. Med. Inform. 2018, 114, 88-100. [CrossRef] [PubMed]

64. Chen, Y.; Wang, S.; Yao, J.; Li, Y.; Yang, S. Socially responsible supplier selection and sustainable supply chain development: A combined approach of total interpretive structural modeling and fuzzy analytic network process. Bus. Strat. Environ. 2018, 27, 1708-1719. [CrossRef]

65. Kayastha, P.; Dhital, M.; De Smedt, F. Application of the analytical hierarchy process (AHP) for landslide susceptibility mapping: A case study from the Tinau watershed, west Nepal. Comput. Geosci. 2013, 52, 398-408. [CrossRef]

66. Vinogradova, I.; Podvezko, V.; Zavadskas, E.K. The Recalculation of the Weights of Criteria in MCDM Methods Using the Bayes Approach. Symmetry 2018, 10, 205. [CrossRef]

67. Sun, C.-C. A performance evaluation model by integrating fuzzy AHP and fuzzy TOPSIS methods. Expert Syst. Appl. 2010, 37, 7745-7754. [CrossRef]

68. Gumus, A.T. Evaluation of hazardous waste transportation firms by using a two step fuzzy-AHP and TOPSIS methodology. Expert Syst. Appl. 2009, 36, 4067-4074. [CrossRef]

69. Hsieh, T.-Y.; Lu, S.-T.; Tzeng, G.-H. Fuzzy MCDM approach for planning and design tenders selection in public office buildings. Int. J. Proj. Manag. 2004, 22, 573-584. [CrossRef]

70. Hermida, M.A.; Cabrera, N.; Calle, C. La densidad urbana como variable de análisis de la ciudad: El caso de Cuenca, Ecuador. EURE 2015, 41, 25-44. [CrossRef]

71. Loibl, W.; Etminan, G.; Gebetsroither-Geringer, E.; Neumann, H.-M.; Sanchez-Guzman, S. Characteristics of Urban Agglomerations in Different Continents: History, Patterns, Dynamics, Drivers and Trends. In Urban Agglomeration; IntechOpen: London, UK, 2018.

72. Moyano, C.M.; Ortega, J.F.; Mogrovejo, D.E. Efficiency analysis during calibration of traffic microsimulation models in conflicting intersections near Universidad del Azuay, using Aimsun 8.1. In Proceedings of the MOVICI-MOYCOT 2018: Joint Conference for Urban Mobility in the Smart City, Medellin, Colombia, 18-20 April 2018.

73. Ortega, J.; Tóth, J.; Péter, T. Estimation of Parking Needs at Light Rail Transit System Stations. Available online: https://www.researchgate.net/publication/331976894_Estimation_of_parking_needs_at_Light_Rail_ Transit_System_stationsISBN_978-963-8121-85-1 (accessed on 30 April 2019).

74. Ortega, J.; Tóth, J.; Péter, T. A Spatial Study of the Catchment Area of P\&R Facilities. Available online: https://www.researchgate.net/publication/341978299_A_spatial_study_of_the_catchment_area_of_ PR_facilities (accessed on 12 March 2020).

75. Cuenca Municipality. Sustainable Urban Mobility Plan and Public Areas, I; Cuenca Municipality: Cuenca, Ecuador, 2014.

76. Cohen, P.; Potchter, O.; Schnell, I. The impact of an urban park on air pollution and noise levels in the Mediterranean city of Tel-Aviv, Israel. Environ. Pollut. 2014, 195, 73-83. [CrossRef]

(C) 2020 by the authors. Licensee MDPI, Basel, Switzerland. This article is an open access article distributed under the terms and conditions of the Creative Commons Attribution (CC BY) license (http://creativecommons.org/licenses/by/4.0/). 